\title{
Evaluation of Some Physicochemical Parameters of Compost Produced from Coffee Pulp and Locally Available Organic Matter at Dale District, Southern Ethiopia
}

Giche Yadesa Hirpa ( $\sim$ gicheyadesa4@gmail.com )

\section{Research}

Keywords: Composting, Experiment, Physicochemical parameters, Proportions, Treatment

Posted Date: June 4th, 2020

DOI: https://doi.org/10.21203/rs.3.rs-26668/v1

License: (c) (1) This work is licensed under a Creative Commons Attribution 4.0 International License. Read Full License 


\section{Abstract}

Background: Inadequate disposal of coffee waste have led to serious environmental problems, and requiring efficient measures to recycling these wastes. Composting is thus, environmental friendly option for utilization of this waste. Therefore this study was to evaluate some physicochemical parameters of compost produced from coffee pulp with cow dung and enset leaf (Ensete ventricosum).

Results: Treatments were built in randomized complete block design with proportions of treatment one ( $90 \%$ of coffee pulp and $10 \%$ of top soil), treatment two ( $65 \%$ of coffee pulp, $25 \%$ of cow dung and $10 \%$ of top soil), treatment three (65\% of coffee pulp, $25 \%$ of enset leaf and $10 \%$ of top soil) and treatment four ( $50 \%$ of coffee pulp, $20 \%$ of cow dung, $20 \%$ of enset leaf and $10 \%$ of top soil). It conducted for 80 days, from December 28, 2018 to March 17, 2019. Some physicochemical parameters were determined at 25,55 and 80 days of composting and mean value of bulk density, moisture content, $\mathrm{pH}$, electric conductivity, organic matter, total organic carbon, total nitrogen, total phosphorous, total potassium and $\mathrm{C} / \mathrm{N}$ ratio were $483.6 \mathrm{~kg} / \mathrm{m} 3-487.11 \mathrm{~kg} / \mathrm{m} 3,50.74-52.43 \%, 7.45-8.36,3.08 \mathrm{mS} / \mathrm{cm}-3.42 \mathrm{mS} / \mathrm{cm}$, $45.26 \%-46.99 \%, 26.19 \%-27.27 \%, 1.54 \%-1.61 \%, 0.41 \%-0.59 \%, 0.75 \%-1.15 \%$ and $17.5-18.44$ respectively.

Conclusions: $p \mathrm{H}$ of treatment four was more neutral than from all and total potassium of treatment four was more nutrient content than the rest. Thus, experimental results showed that treatment four was better for quality compost preparation and provides baseline information for coffee pulp waste management simultaneously.

\section{Background}

The world coffee production depends on two species, Coffea arabica L. and Coffea canephora. Arabica or highland coffee ( $C$. arabica $L$.) accounts for $2 / 3$ of world coffee production and the left over portion comes from $C$. canephora (Labouisse et al., 2008). Arabica coffee is the coffee species grown in Ethiopia and the country is the primary center of origin and genetic diversity for this crop (Vega, 2008). Ethiopia is the first producer and exporter in Africa and 5th in the world (ICO, 2013).

Coffee farming systems in Ethiopia categorized into four. They are forest coffee, semi - forest coffee, garden coffee, and plantation coffee. According to Taye Kufa (2013) from total production of coffee; forest coffee, semi-forest coffee, garden coffee and plantation coffee constituted $10 \%, 35 \%, 55 \%$, and $8 \%$ of the total production respectively.

Coffee is one of the most important agricultural export commodities in the world economy, next to oils and it is the most important and strategic commodity on which Ethiopia's economy depends on. From the time age-old, the coffee sector is one of the backbones of the economic and social development in Ethiopia (Tadesse Woldemariam and Feyera Senbeta, 2008).

Because of economic importance, coffee production and its processing were increased. The processes were involving either dry or wet processing method for the removal of coffee husk and pulp (Pandey et al., 
2000). This process represents serious environmental problem contains high content of tannins, phenolic compounds and chlorogenic acids that could inhibit plant root growth and lead in greenhouse gas emissions through anaerobic decomposition that necessitates the proper use and disposal of coffee waste (Fan et al., 2003; Murthy and Naidu, 2012).

Regardless of its contribution to the national as well as the regional economy, the coffee sector is the most unsustainable sector due to environmental solid waste management is not concerned. The current practices of green coffee bean production are not promoting the health of the community as well as wellbeing of the land on which coffee cherries are being produced. The residue from dry coffee processing is burnt while those from wet processing are dumped into environment, both being disposed into landfills and surface water and cause environmental problem (Alemayehu Haddis and Rani, 2008) thus safe and environmentally harmonious management of solid wastes becomes a major issue for these nations. Thus, there is a need to find alternative uses for these residues.

Also in Ethiopia, most people of dependend on ensete (ensete ventricosum) and used for food in the form of kocho and amicho (e.g., the Sidama people) (Ferew Kebede, 2012). However, its leaf was disposed into the local environment during this process. Thus, sustainable solutions must be sought for its better management.

Because of the economic significance coffee and enset farming is increased in Dale district through a time. During the processing for use, these farm release huge amount of waste. These wastes were possessed significant environmental effects, because of poor management of solid waste in the Dale district. However, these wastes are rich in organic matters, for the production of value added products like, compost. Compost is the solution and alternative use of the coffee pulp Henok Kassa and Tenaw Workayew, 2014; Fekadu Shemekite et al., 2014). Composting of coffee by-product with agricultural waste such as cow dung, chat, flower leaf, Millettia ferruginea and also with sawdust and effective microorganism was carried out at different proportion (Franca et al., 2009; Henok Kassa and Tenaw Workayew, 2014; Fekadu Shemekite et al., 2014; Gezahegn Degefe et al., 2016). However, no research was carried out to investigate the proportion of composting of coffee pulp with enset leaf (Ensete ventricosum) and cow dung at different proportions.

A study was, therefore, made to understand the changes during composting of coffee pulp amended alone or together with cow dung and enset leaf at different proportions. High qualities of compost were produced by monitoring factor affecting composting process. In order to identify quality of compost produced, physicochemical properties of the compost were determined during composting period up to maturity stages and compare to compost quality standard set up by different countries like Dutch, Belgium and Italy (Brinton, 2000) including Ethiopia (EEPA, 2004).

Thus, this study was intended to evaluate some physicochemical parameters of compost produced from coffee pulp with and without locally available organic matter (cow dung and enset) at Dale district. 


\section{Methodology}

\subsection{Description of Study Area}

Dale district located in Sidama Zone, Southern Nation, Nationalities and Peoples Region of Ethiopia (Fig. 1). It is located within $38^{\circ} 20^{\prime} 7.8^{\prime \prime}-38^{\circ} 32^{\prime} 36.5^{\prime \prime} \mathrm{E}$ and $06^{\circ} 28^{\prime} 15.5^{\prime \prime}-07^{\circ} 04^{\prime} 50.3^{\prime \prime} \mathrm{N}$ at an altitude of 1750 masl. The major town in Dale is Yirgalem. The area receives an annual minimum and maximum rainfall 858.1 and $1676.3 \mathrm{~mm}$, respectively. The annual average minimum and maximum air temperatures are $11.00 \mathrm{C}$ and $28.40 \mathrm{C}$, respectively. The major soil types of the center are eutric-nitosol and chromotic-cambisols that are highly suitable for coffee production (Bayetta Belachew, 2001).

\subsection{Composting Materials}

The basic organic raw materials used for composting included coffee pulp (CP), caw dung (CD), and Enset (false banana) (EL). CP was collected from Shoye kebele cooperative union wet and dry coffee processing firms directly from their dumping sites. CD and EL was collected from the Shoye kebele farmer's household. Finally the common bulking agent top soil was taken from the Shoye cooperative union's land area.

\subsection{Research Design}

Before the start of the composting process, raw materials were crushed by a hammer mill. Then the initial moisture content was adjusted to approximately $50-55 \%$ by water spraying according to Zhang et al. (2016). Subsequently, four different treatments each having three replication with the total of 12 treatment were prepared in randomized complete block design containing different composition of coffee pulp, cow dung, enset leaf and top soil. The treatment was prepared by the proportion indicated in Table 1 below. Treatments were assigned at random to the blocks and each treatment appeared once in each block (Fig. 2). The composts base area was $1 \mathrm{~m} 2$ and $1 \mathrm{~m}$ long ( $1 \mathrm{~m}^{3}$ in volume) and prepared by Windrow method. The experiment was conducted for 80 days, from December 28, 2018 to March 17, 2019 , at Dale district. Treatments were placed on a plastic sheet membrane to prevent the dispersion of any leachate generated and mixing of treatment with soil during the composting experiments. The treatment was covered by grass for the protection of water loss. The compost piles were turned ones and watered twice per week uniformly for all the treatments for the first two months and once per week later on to enhance the composting process by blending and breaking up the composting materials according to Dessalegn Dadi et al. (2012).

Top soil was added to each layer to aid composting process. 
Table 1

Percentage proportion of composting materials.

\begin{tabular}{|lllll|}
\hline Heap type & \multicolumn{2}{l}{ Treatment } & & \\
\cline { 2 - 5 } & T1 & T2 & T3 & T4 \\
\hline CP & $90 \%$ & $65 \%$ & $65 \%$ & $50 \%$ \\
\hline CD & -- & $25 \%$ & -- & $20 \%$ \\
\hline EL & -- & -- & $25 \%$ & $20 \%$ \\
\hline Top soil & $10 \%$ & $10 \%$ & $10 \%$ & $10 \%$ \\
\hline
\end{tabular}

\subsection{Data Collection}

Some physicochemical parameters of sample of raw materials used for composting were analyzed before starting composting process in order to know physicochemical quality of the raw material. After starting composting process up to the ending of the composting process, three samples were taken at 25 , 55 and 80 days from each treatment and replication from corner and center of the heap and mixed together to get homogeneous and representative samples. The samples were grinded using a grinder to pass through less than $2 \mathrm{~mm}$ sieve for parameter analysis. Some Physicochemical parameters were determined for all treatments at different times of composting and analyzed at Ambo University Chemistry Department Laboratory.

\subsection{Method of Physicochemical Analysis}

Bulk density (BD): Bulk density ( $\mathrm{kg} / \mathrm{m} 3)$ was determined by dividing weight of samples to volume of container according to Tiquia et al. (2002).

Moisture Content (MC): Five gram of the representative fresh sample was weighed for the determination of moisture content in a clean, dry, pre-weighed and recorded moisture free tin and loaded in an oven at $1050 \mathrm{C}$ up to a constant weight (24 hours). Oven dried samples were cooled in desiccators for 30 minutes and reweighed (Sahlemedhin Sestu and Taye Bekele, 2000).

Determination of $\mathrm{pH}$ : A sub-sample ( $5 \mathrm{~g}$ ) of air dried ground compost was transferred into a flask and $25 \mathrm{ml}$ of distilled water for 1:5 compost/water suspension. The flasks were covered and shaken mechanically for 15 minute and allowed to stand for 30 minute. The $\mathrm{pH}$ of the suspension was measured using an electronic pH meter (Sahlemedhin Sestu and Taye Bekele, 2000).

Determination of OM and TOC: Five gram of air-dry sample was weighed and transferred to a $500 \mathrm{ml}$ Erlenmeyer flask. $10 \mathrm{ml} 1 \mathrm{~N} \mathrm{K2Cr207}$ solution with pipette was added into both samples and blanks. Carefully $20 \mathrm{ml}$ concentration $\mathrm{H} 2 \mathrm{SO} 4$ added into fume cupboard and swirled the flask and allowed standing asbestos or corking pad for 30 minutes. Then $200 \mathrm{ml}$ of distilled water was added and allowed it to cool. $10 \mathrm{ml}$ concentrations of Orthophosphoric acid and $0.5 \mathrm{ml}$ of barium diphenylamine sulphonate 
were added on indicator just before titration. Titrating both samples and blanks with $0.5 \mathrm{~N}$ ferrous sulfate solution until the color changed to purple or blue, then added ferrous sulfate solution drop by drop until the color flashed to green then continued to a light green end point (Sahlemedhin Sestu and Taye Bekele, 2000).

Total nitrogen (TN): Nitrogen in the sample was estimated by following the micro kjeldhal method as (Sahlemedhin Sestu and Taye Bekele, 2000).

Carbon to nitrogen ratio: The carbon to nitrogen ratio was calculated from the respective organic carbon and nitrogen values according to Tandon (2005). Carbon was divided by nitrogen to find the ratio of carbon to nitrogen.

Total phosphorous was determined by following methods of Sahlemedhin Sestu and Taye Bekele (2000).

Electrical Conductivity was analyzed by direct measuring solution of compost made by adding distilled water into compost sample in 1:5 ratios. The conductance cell was washed with distilled water and immersed into solution of compost and the reading was note on EC meter (Sahlemedhin Sestu and Taye Bekele, 2000).

Total Potassium was determined using flame-photometer according to Sahlemedhin Sestu and Taye Bekele, (2000) methods.

\subsection{Data Analysis}

Experiments were expressed in tables and figures. For this purpose statistical software, SAS version 9.0 was used to determine the statistically significant differences between the treatments by general linear models). Duncan's least significance difference test was used to separate means of all measurements at 0.05 confidence levels.

\section{Results And Discussions}

\subsection{Physicochemical Characterization of Feedstock}

Determination of some physicochemical characteristics of feedstock materials used for composting (Table 2) was analyzed for adjusting parameters that have a huge impact on the composting process. 
Table 2

Some physiochemical characteristics of raw materials.

\begin{tabular}{|c|c|c|c|c|c|c|c|c|c|}
\hline \multirow{2}{*}{$\begin{array}{l}\text { Raw } \\
\text { material }\end{array}$} & \multicolumn{9}{|c|}{ Parameters } \\
\hline & $\begin{array}{l}\mathrm{MC} \\
(\%)\end{array}$ & $\mathrm{pH}$ & $\begin{array}{l}\mathrm{EC} \\
(\mathrm{mS} / \mathrm{cm})\end{array}$ & $\begin{array}{l}\text { TOC } \\
(\%)\end{array}$ & $\begin{array}{l}\text { OM } \\
(\%)\end{array}$ & $\begin{array}{l}\text { TN } \\
(\%)\end{array}$ & $\begin{array}{l}\text { TP } \\
(\%)\end{array}$ & $\begin{array}{l}\text { TK } \\
(\%)\end{array}$ & $\mathrm{C} / \mathrm{N}$ \\
\hline $\mathrm{CP}$ & 58.02 & 4.64 & 7.74 & 40.31 & 69.5 & 1.05 & 1.11 & 2.49 & 38.39 \\
\hline$C D$ & 50.76 & 8.73 & 5.95 & 33.31 & 57.42 & 1.25 & 1.43 & 1.99 & 26.65 \\
\hline EL & 61.34 & 6.3 & 4.69 & 46.93 & 80.9 & 1.50 & 1.36 & 3.66 & 31.29 \\
\hline
\end{tabular}

\subsection{Physicochemical Parameters of Composting}

\subsubsection{Bulk Density}

The bulk density increased with time of composting was $435.75 \mathrm{~kg} / \mathrm{m} 3$ at D25 through $475.5 \mathrm{~kg} / \mathrm{m} 3$ at D55 to $546.42 \mathrm{~kg} / \mathrm{m} 3$ at D80 (Fig. 3). This might be attributed to decomposition rate of organic matter which increases BD as composting time proceeds. This result was in agreement with the findings of Elhaddad et al. (2014) who states that BD of compost produced from rice straw increased as organic matter in the compost decreased. Thus, organic matter decreased as composting process proceeded. BD increased since organic matter and bulk density have inverse relationships.

As shown in Table 4 there were no significant difference between T1, T2, T3, and T4 at $p>0.05$ confidence level. The results revealed that all the compost types had comparable value of BD was might be due to the comparable content of organic matter i.e if organic content of compost was similar the BD was also similar and vice versa. The BD of this result was between $483.3-487.11 \mathrm{~kg} / \mathrm{m} 3$ (Table 3 ). This result was agreed with BD of good quality compost mentioned by Muno (2003) that was greater than $460 \mathrm{~kg} / \mathrm{m} 3$. Similarly it is agreed with the results reported by El-haddad et al. (2014) who found that bulk density of compost produced from rice straw with other organic waste and/or tea wastes were beween 463.3 to $683.3 \mathrm{~kg} / \mathrm{m} 3$.

Table 3

Bulk density of different composts.

\begin{tabular}{|ll|}
\hline Compost & BD $(\mathrm{kg} / \mathrm{m} 3)$ \\
\hline T1 & $483.6 \mathrm{a}$ \\
\hline T2 & $487.11 \mathrm{a}$ \\
\hline T3 & $486.22 \mathrm{a}$ \\
\hline T4 & $486.56 \mathrm{a}$ \\
\hline LSD $(5 \%)$ & 19.26 \\
\hline Means with different letter are significantly different at $\mathrm{p}<0.05$ \\
\hline
\end{tabular}




\subsubsection{Moisture Content}

The moisture content decreased with the increase in composting time from $61.64 \%$ at D25 through $52.64 \%$ at D55 to 41.36 at D80 (Fig. 4). This might be due to water losses that occurred during composting process. The reduction in moisture at the end of composting process might be due to microbial heat generation causing improved aridness. Drastic decrease in moisture content due to evaporation of water as a result of intense microbial activities and generation of energy at the earlier period of composting was also reported by Fekadu Shemekite et al. (2014). This result was also agreed with the study of Henok Kassa and Tenaw Workayew (2014) which reported that MC of compost was decreased from $61.1-54 \%$ during composting time due to loss of water through evaporation.

The difference in MC was observed among the different composts of T1 and T4, T2 and T4, T3 and T4 (Table 4). This might be due to the combination of three different composting raw materials in $\mathrm{T} 4$ and lower water holding capacity. The result of this study (Table 5) was consistent with Biotreat (2003) and USCC (2003) reported that MC of compost ranges from $40-65 \%$. Similarly the MC of study compost was found to be within acceptable ranges of $40-60 \%$ suggested by the EEPA (2004).

Table 4

Moisture content of different composts.

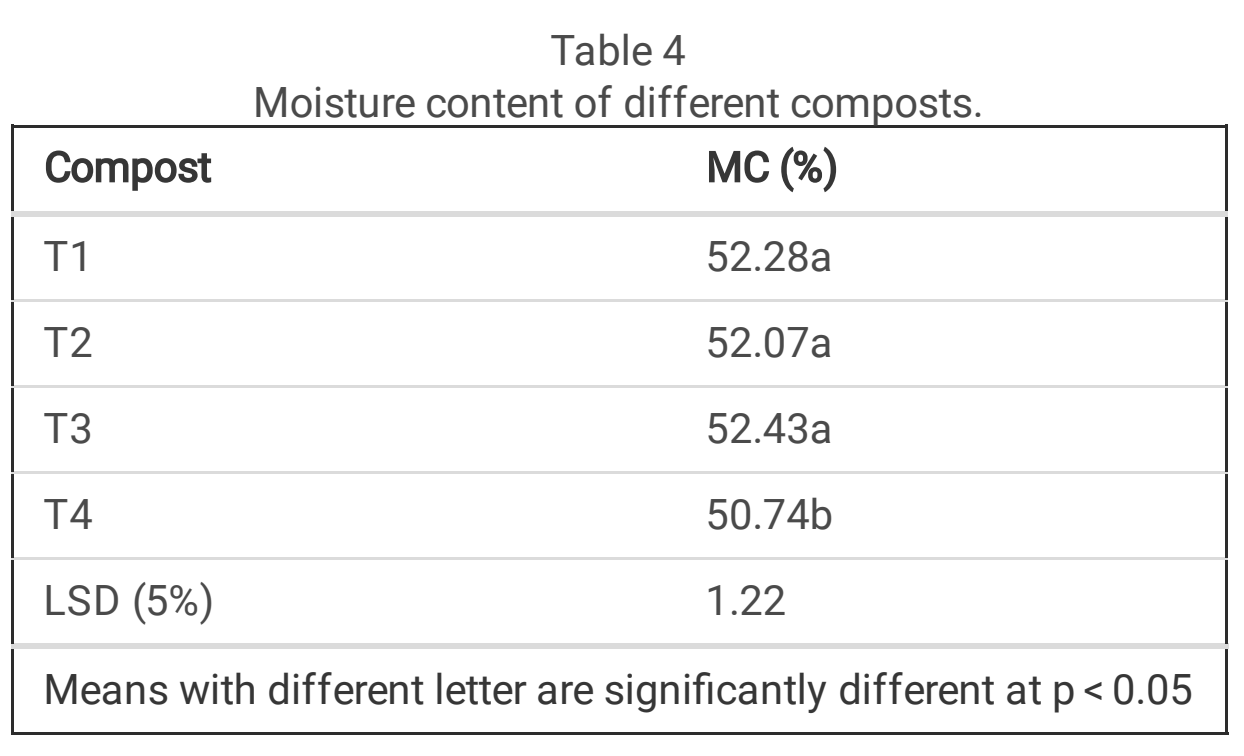

\subsection{3 pH}

The mean pH of the composts increased from D25 to D55 and then decreased at D80 during composting time (Fig. 5). The increase of pH during composting from D25 to D55 might indicate ammonification processes as a result of microbial activities. These results are consistent with Andrea et al., (2018) which states that the $\mathrm{pH}$ of compost produced from municipal waste increased at initial process. Reduction of pH was observed from D55 to D80. This result was consistent with Gezahegn Degefe et al. (2016), who reported that the $\mathrm{pH}$ of compost declined at the maturity stage. Similarly Tadesse Getahun et al. (2012b) reported that the $\mathrm{pH}$ of compost produced from biodegradable municipal solid waste decreased from 8.3 at central stage of composting to 7.7 in the final phase of composting. The decreased in $\mathrm{pH}$ of decomposing organic materials at final stage might be due to the production of organic acids, phenolic compounds and increased in $\mathrm{pH}$ at initial stage might be due to the formation of ammonia during decomposition was also reported by Preethu et al. (2007). 
As shown in Table 5 below there was no significant difference between T1 and T2. However there were significance difference between $\mathrm{T} 1$ and $\mathrm{T} 3, \mathrm{~T} 1$ and $\mathrm{T} 4, \mathrm{~T} 2$ and $\mathrm{T} 3, \mathrm{~T} 2$ and $\mathrm{T} 4, \mathrm{~T} 3$ and $\mathrm{T} 4$. The difference in $\mathrm{pH}$ among the composted types might be due to the differences in chemical composition of the starting materials, the mixing ratio and the interaction within the composted materials during composting (Dessalegn Dadi, 2018). The combined effects of ammonification and accumulation of organic acids also regulate the $\mathrm{pH}$ dynamics during the composting process (Liu and Price, 2011). For all compost types, the $\mathrm{pH}$ of compost samples was measured to be slightly neutral to slightly basic (7.45-8.36) (Table 5). This result was in agreement with different country composting standard guideline including Dutch, Belgium and Italy which is $6.5-8.5$ (Brinton, 2000). The pH of T4 was slightly neutral and there is no need of chemicals to adjust the $\mathrm{pH}$ before using it for soils. Also as $\mathrm{pH}$ goes much above the limiting point, micronutrients and phosphorous become less available to roots (USCC, 2003). Thus, T4 is more preferable than T1, T2 and T3 as it can be applied to soil without any treatment of its $\mathrm{pH}$.

Table 5

$\mathrm{pH}$ of different composts.

\begin{tabular}{|ll|}
\hline Compost & pH \\
\hline T1 & $8.14 \mathrm{ab}$ \\
\hline T2 & $8.34 \mathrm{ab}$ \\
\hline T3 & $8.36 \mathrm{a}$ \\
\hline T4 & $7.45 \mathrm{~b}$ \\
\hline LSD $(5 \%)$ & 0.37 \\
\hline Means with different letter are significantly different at $\mathrm{p}<0.05$ \\
\hline
\end{tabular}

\subsubsection{Electrical Conductivity}

The EC of the compost increased from $2.13 \mathrm{mS} / \mathrm{cm}$ at D25 to $4.63 \mathrm{mS} / \mathrm{cm}$ at D55 (Fig. 6). This might be due to the organic matter degradation and release of different mineral salts in available forms (such as phosphate, ammonium, and potassium). However, at the later stage of composting it was observed that the EC decreased from $4.63 \mathrm{mS} / \mathrm{cm}$ at D55 to $2.86 \mathrm{mS} / \mathrm{cm}$ at D80 (Fig. 6). This might be due to consumption of produced organic acids at the process and their conversion to ammonia. These results are in agreement with findings previously reported by Jayapriya et al. (2015) who found that the EC of the compost produced from yard waste increased at initial phase and decreased at latter stage of composting.

As shown in Table 6 below there were no significant difference among T1, T2, T3, and T4 at $p>0.05$ confidence level. This is might be due to similar release and the conversion of soluble salt into ammonia (Wang et al., 2004). This non-significance difference in EC among the compost types might be due to similar interaction within the composted materials during composting time. The EC value of this compost was between $3.08 \mathrm{mS} / \mathrm{cm}$ to $3.42 \mathrm{mS} / \mathrm{cm}$ (Table 6). This result was in agreement with the study by Muno 
(2003) which reported that the EC values between $2 \mathrm{mS} / \mathrm{cm}$ to $6 \mathrm{mS} / \mathrm{cm}$ and agreed with the finding of Mahabub Yusuf (2008), which indicated the EC values of matured compost in the range of $2.19 \mathrm{mS} / \mathrm{cm}$ to $9.32 \mathrm{mS} / \mathrm{cm}$. This finding is agreement with the study by Reyes-torres et al. (2018) who state that EC of compost produced from green waste was $0.46 \mathrm{mS} / \mathrm{cm}$ to $3 \mathrm{mS} / \mathrm{cm}$. This study was also in agreement with the quality compost used by different countries such as Dutch, Belgium, and Italy that is less than $5 \mathrm{mS} / \mathrm{cm}$ (Brinton, 2000).

Table 6

Electrical conductivity of different composts.

\begin{tabular}{|ll|}
\cline { 2 - 3 } & \multicolumn{2}{|l|}{ Compost } & EC \\
\hline T1 & $3.17 \mathrm{a}$ \\
\hline $\mathrm{T} 2$ & $3.17 \mathrm{a}$ \\
\hline $\mathrm{T} 3$ & $3.08 \mathrm{a}$ \\
\hline $\mathrm{T} 4$ & $3.42 \mathrm{a}$ \\
\hline LSD $(5 \%)$ & 0.56 \\
\hline & Mean with different letter are significantly different at $\mathrm{p}<0.05$ \\
\hline
\end{tabular}

\subsubsection{Organic Matter}

Organic matter was highest at D25 (50.04\%) and lowest at D80 (39.7\%) (Fig. 7). This is might be due to various biochemical reactions that transform complex substrates to simpler components that result in a reduction of OM percentage (Zhang et al., 2016). The reason for the reduction in total organic matter is also the mineralization of organic matter into $\mathrm{CO} 2$ during the composting process by microorganisms leading to decrease in total organic matter at the latter stage of the process (Tadesse Getahun et al., 2012b). The reduction in organic matter with time was also reported by Dessalegn Dadi et al. (2012) who found that OM of compost decreased from $35.64-19.50 \%$.

As shown in Table 7 below there were no significant differences among all treatments. This might be attributed to the similar microbial activity in all treatments, which promoted the decomposition and transformation of organic matter into carbon dioxide, energy and stable compounds. Dessalegn Dadi (2018) reported that organic matter of compost produced from different types of raw material was the same as compost produced from homogenous material due to similar microbial activity in the composting types. The value of OM of the compost ranged between $45.16 \%-46.99 \%$ (Table 7 ). This result was in agreement with the finding of Dessalegn Dadi et al. (2012) who found that organic matter of the compost produced from solid waste was between $17.46 \%-47.64 \%$. The result obtained in all compost types were in agreement with the quality compost criteria used by different countries such as Dutch, Belgium and Italy which is $>20 \%$ (Brinton, 2000). The EEPA (2004) reported that the lowest critical threshold level of $\mathrm{OM}$ is $30 \%$ which is in line with the present finding. 
Table 7

Organic matter of different composts.

\begin{tabular}{|ll|}
\hline Compost & OM (\%) \\
\hline T1 & $46.87 a$ \\
\hline T2 & $45.16 a$ \\
\hline T3 & $45.97 a$ \\
\hline T4 & $46.99 a$ \\
\hline LSD (5\%) & 2.6 \\
\hline Mean of different letter are significantly different at $p>0.05$ \\
\hline
\end{tabular}

\subsubsection{Total Organic Carbon}

Total organic carbon content decreased from $29.03 \%$ at D25 through $28.43 \%$ at D 55 to $23.03 \%$ at D80 with the increase in compositing time (Fig. 8). As the composting time extended, the total carbon content was decreased. This might be due to decomposition of the organic matter by microorganisms. Bernal et al. (2009) also states that the degradation rate of carbon decreases gradually as composting progresses because of the reduction in available carbon sources because of the evolution of carbon dioxide. This reduced TOC was in agreement with Tadesse Getahun et al. (2012b) who stated that loss of TOC from about $44 \%$ at the beginning to $17 \%$ at maturity phase due to evolution of carbon dioxide. Fekadu shemekite et al. (2014) also reported a decrease in total organic carbon in vegetable amended with coffee husk composting during 90 days of compost.

The TOC of composts were no significantly different between T1, T2, T3, and T4 (Table 8). It was observed that comparable amounts of organic carbon were obtained for compost of all types (T1, T2, T3 and T4). This might be due to the presence of comparable amount of organic matter content in all treatments. The value of TOC of these composts ranged between $26.19 \%-27.27 \%$ (Table 8). This result was supported with the study by Fekadu Shemekite et al. (2014) who found that the total organic carbon was $24.5-48.1 \%$. This result was in agreement with the finding of Dayanand et al. (2017) reported that the mean of total organic matter of compost produced from flower waste was between $15.5 \%-30.9 \%$. 
Table 8

Total organic carbon of different composts.

\begin{tabular}{|ll|}
\hline Compost & TOC (\%) \\
\hline T1 & $27.19 a$ \\
\hline T2 & $26.19 a$ \\
\hline T3 & $26.66 a$ \\
\hline T4 & $27.27 a$ \\
\hline LSD (5\%) & 1.51 \\
\hline Mean with different letters are significantly different at $p<0.05$ \\
\hline
\end{tabular}

\subsubsection{Total Nitrogen:}

Nitrogen content was increased as time of composting extended, and there was $0.15 \%, 0.63 \%$ and $0.68 \%$ at D25, D55 and D80 respectively (Fig. 9). Total nitrogen showed an increasing trend with composting duration which might be due to the concentration effect caused by carbon loss associated with mineralization of the organic matter. This result was in agreement with the finding of Fekadu Shemekite et al. (2014) who state that the TN content of compost increases with increasing duration of composting time. These total nitrogen content was observed to increase with time are in agreement with some other studies (Preethu et al., 2007 and Liu and Price, 2011). Fekadu Shemekite et al. (2014), reported that increment in the TN content of compost produced from coffee husk was from $2.8-3.2 \%$ with progressing decomposition time.

As shown in Table 9 below there were no significant differences among all treatments ( $T 1, T 2, T 3$, and T4). The similarity in TN content among the compost types might be due to the similarity in the mineralization/immobilization of nitrogen and the interaction within the composting materials. Also the non-significance difference between composting types might be due to the slightly similar amount of nitrogen content in the starting raw materials (Dessalegn Dadi, 2018). The mean of TN of those all compost was $1.55-1.61 \%$ (Table 9). This result was in agreement with TN in compost reported by Herity (2003) that is $1 \%-3 \%$ and by Abebe Sisay (2015) that is $1.3 \%-1.9 \%$. Similarly this finding was in agreement with the study reported by Reyes-torres et al. (2018) who states that TN of compost produced from green waste was $0.41 \%-3.40 \%$. Also this result was in agreement with the quality compost criteria, which is used by different counties such as Dutch, Belgium and Italy that is $>0.7 \%$ (Brinton, 2000). 
Table 9

Total nitrogen of different composts.

\begin{tabular}{|l|l|}
\hline Compost & TN $(\%)$ \\
\hline T1 & $1.55 a$ \\
\hline T2 & $1.54 a$ \\
\hline T3 & $1.61 a$ \\
\hline T4 & $1.60 a$ \\
\hline LSD (5\%) & 0.22 \\
\hline Means with different letters are significantly different at $p<0.05$ \\
\hline
\end{tabular}

\subsubsection{Carbon to Nitrogen Ratio}

The carbon to nitrogen ratio decreased with increasing composting time and there was $22.53,18.49$ and 12.7 decreased in $\mathrm{N}$ content at D25, D55 and D80 respectively (Fig. 10). The $\mathrm{C} / \mathrm{N}$ ratio of all composting types varied with time. In general, the $\mathrm{C} / \mathrm{N}$ ratio of all composting types was observed to decline with time, which might indicates that formation of stable product. The $\mathrm{C} / \mathrm{N}$ ratio decreased significantly over time as carbon was lost in the form of $\mathrm{CO} 2$ through microbial respiration as also reported by Ryckeboer et al. (2003b). This study was consistent with the work of Fekadu Shemekite et al. (2014) and Gezahegn Degefe et al. (2016) which stated that the $\mathrm{C} / \mathrm{N}$ ratio of compost decreased as the composting period was extended. Decrease of the $\mathrm{C} / \mathrm{N}$ ratio reflects the organic matter mineralization and an adequate evolution of the microbial composting process and $\mathrm{C} / \mathrm{N}$ ratio is expected to reach minimum values when mineralization of organic matter has finished (Gezahegn Degefe et al., 2016).

Carbon to nitrogen ratio was no significantly different among all treatments $(T 1, T 2, T 3$, and $T 4)$ to the other (Table 10). This might be due to the comparable amount in the organic carbon content in the composted material and the similarity in the role of microorganisms during composting. This result was in agreement with the work of Dessalegn Dadi (2018) who found that the $\mathrm{C} / \mathrm{N}$ ratio of compost produced from coffee by-product ranged 14.29-22.28. The result of all these composting types are within the range of EEPA (2004) guidelines reported the $\mathrm{C} / \mathrm{N}$ ratio of good quality compost was less or equal to 29 : 1. Also the $\mathrm{C} / \mathrm{N}$ ratio of the studied compost was in agreement with the compost quality standards used by different countries such as Dutch, Belgium and Italy that is less than 20: 1 (Brinton, 2000). 
Table 10

Carbon to nitrogen ratio of different composts.

\begin{tabular}{|c|c|}
\hline & \\
\hline Compost & $\mathrm{C} / \mathrm{N}$ ratio \\
\hline $\mathrm{T} 1$ & $18.44 a$ \\
\hline $\mathrm{T} 2$ & $17.61 a$ \\
\hline T3 & $17.50 \mathrm{a}$ \\
\hline $\mathrm{T} 4$ & $18.08 a$ \\
\hline LSD (5\%) & 2.74 \\
\hline \multicolumn{2}{|c|}{ Means with different letters are significantly different at $p<0.05$} \\
\hline
\end{tabular}

\subsubsection{Total Phosphorous}

Total Phosphorous of composting increased as time of compost was proceeded (Fig. 11). The increase of TP concentration during the composting process was attributed to the solubilization of inorganic phosphate by microorganism existing in the compost. This result was in agreement with the study of Dessalegn Dadi et al. (2012) who sated that the total phosphorous content produced from solid waste increased from $0.33-0.66 \%$ during composting time.

Total phosphorus was not significantly different among the different composting treatments ( $T 1, T 2, T 3$ and T4) (Table 11). The total phosphorous recorded in this study was slightly similar among all composting piles. This might be due to the release of available phosphorous during decomposition of organic phosphorous and the similarity in composting system at time. Also the similarity of total phosphorus among the composted types might be due to the available microorganisms and the similarity in the interaction within the composited during composting time. The Total phosphorous content of this study was found between $0.41-0.59 \%$ (Table 11). The result obtained were in agreement with the study reported by Muno (2003) and Travis et al. (2003) that total phosphorous ranged between $0.4-1.1 \%$. The result was also in agreement with the finding of Endale Werako (2016) who found that the TP of compost produced from coffee by- product ranged between $0.25 \%-1.02 \%$. 
Table 11

Total phosphorous of different composts.

\begin{tabular}{|ll|}
\cline { 2 - 3 } Compost & TP (\%) \\
\hline T1 & $0.51 \mathrm{a}$ \\
\hline T2 & $0.41 \mathrm{a}$ \\
\hline T3 & $0.42 \mathrm{a}$ \\
\hline T4 & $0.59 \mathrm{a}$ \\
\hline LSD $(5 \%)$ & 0.25 \\
\hline Mean with different letter are significantly different at $\mathrm{p}<0.05$ \\
\hline
\end{tabular}

\subsubsection{Total Potassium}

Total potassium increased as time of composting was extended, that was $0.86 \%, 0.96 \%$, and $1.02 \%$ at D25, D55 and D80 respectively (Fig. 12). This might be due to high decomposition rate of composting materials that increased the amount of potassium and due to the concentration effect caused by carbon loss associated with mineralization of the organic matter as the time of composting was extended. Study by Henok Kassa and Tenaw Workayew (2014) on evaluation of some additives on coffee by-product quality as compost indicated increased in total potassium content in the compost was due to high decomposition rate.

Total potassium content of different composting types ( $\mathrm{T} 1, \mathrm{~T} 2, \mathrm{~T} 3$ and $\mathrm{T} 4)$ was significantly different among $\mathrm{T} 1$ and $\mathrm{T} 4, \mathrm{~T} 1$ and $\mathrm{T} 2, \mathrm{~T} 1$ and $\mathrm{T} 3, \mathrm{~T} 2$ and $\mathrm{T} 4, \mathrm{~T} 3$ and $\mathrm{T} 4$ (Table 12). The higher total potassium content was recorded in T4. This might be due to high decomposition rate of raw composting material. The relatively higher potassium content measured in the composts might be due to the higher concentration of potassium in the combination of $\mathrm{CP}, \mathrm{CD}$ and $\mathrm{EL}$ raw materials simultaneously. This result was in agreement with the finding of Endale Werako (2016) who state that the TK of compost produced from coffee by-product ranged between $0.25 \%-1.48 \%$. Similarly this finding also in agreement with the study reported by Reyes-torres et al. (2018) who stated that TK of compost produced from green waste was $0.26 \%-1.56 \%$. Again Muno (2003) states that the typical range of total potassium in bio waste and green waste compost ranged between $0.6 \%-1.7 \%$. The results obtained in this study also in agreement with the quality compost criteria, which is used by different counties like Dutch, Belgium and Italy that is $>0.75 \%$ (Brinton, 2000). Thus the compost produced from CP, CD and EL (T4) was more preferable to use for fertilizer due to higher content of TK than T1, T2, and T3. 
Table 12

Total potassium of different composts.

\begin{tabular}{|ll|}
\hline Compost & Mean of TK (\%) \\
\hline T1 & $0.75 \mathrm{~b}$ \\
\hline T2 & $0.99 \mathrm{ab}$ \\
\hline T3 & $0.91 \mathrm{ab}$ \\
\hline T4 & $1.15 \mathrm{a}$ \\
\hline LSD (5\%) & 0.25 \\
\hline Mean with different letters are significantly different at $\mathrm{p}<0.05$ \\
\hline
\end{tabular}

\section{Conclusions}

Physicochemical characteristic of composting was analyzed at 25, 55 and 80 days. Mean range specific value of bulk density, moisture content, power of hydrogen, electric conductivity, organic matter, organic carbon, total nitrogen, total phosphorous, total potassium and $\mathrm{C} / \mathrm{N}$ ratio were $483.6 \mathrm{~kg} / \mathrm{m}^{3}$ $487.11 \mathrm{~kg} / \mathrm{m} 3,50.74 \%-52.43 \%, 7.45-8.36,3.08 \mathrm{Ms} / \mathrm{cm}-3.42 \mathrm{Ms} / \mathrm{cm}, 45.26 \%-46.99 \%, 26.19 \%-$ $27.27 \%, 1.54 \%-1.61 \%, 0.41 \%-0.59 \%, 0.75 \%-1.15 \%$ and $17.5-18.44$ respectively. The physicochemical characteristics of compost in this study were included in the range of compost guidelines set by Dutch, Belgium and Italy including Ethiopia.

From this study compost produced from coffee pulp composted with cow dung and enset leaf in the proportion of ( $50 \%$ of CP, $20 \%$ of CD, $20 \%$ of EL and $10 \%$ of top soil) more preferable due to high total potassium content and suitability to use without any treatment of its $P$ h. Thus, the application of coffee pulp composting with cow dung and enset leaf at this proportion can be considered as a technically as well as economically viable option for environmental management in the area of coffee processing stations.

\section{Recommendations}

Based on findings of the study the following recommendations can be made:

- Promoting awareness creation on composting of coffee pulp together with locally available organic matter on the proportion reported in this study for community was needed. Thus, practical use of compost made from coffee pulp and topsoil, coffee pulp, cow dung and top soil, coffee pulp, enset leaf and top soil, and coffee pulp, cow dung, enset leaf and top soil were recommended.

- Introduction of composting system around the coffee processing station might be useful to minimize the environmental impact of coffee waste. 
- Further research should be conducted to determine the level of metals in the compost product, and check the germination, growth, and yield productivity of composted samples using different seeds.

\section{Acronyms And Abbreviation}

\begin{tabular}{|ll|}
\hline C/N & Carbon to Nitrogen ratio \\
\hline CD & Caw Dung \\
\hline CP & Coffee Pulp \\
\hline D25 & Day 25th \\
\hline D55 & Day 55th \\
\hline D80 & Day 80th \\
\hline EL & Enset Leaf \\
\hline EEPA & Ethiopia Environmental Protection Authority \\
\hline ICO & International Coffee Organization \\
\hline MC & Moisture Content \\
\hline MoARD & Ministry of Agriculture and Rural Development \\
\hline OM & Organic Matter \\
\hline SNNPR & Southern Nation Nationalities and Peoples Region \\
\hline TK & Total Potassium \\
\hline TN & Total Nitrogen \\
\hline TOC & Total Organic Carbon \\
\hline TP & Total Phosphorous \\
\hline USCC & United States Composting Council \\
\hline
\end{tabular}

\section{Declarations}

\section{Acknowledgements}

The author gratefully acknowledges the Ambo University Chemistry laboratory for they help during some physiochemical analysis.

\section{Authors' contributions}


Giche Yadesa conceptualized the study. Giche collected and analysed the data, and wrote the draft manuscript; and also he edited and modified the structure of the manuscript.

\section{Funding}

This paper is prepared under the self-sponsor for acquired MSc, to study compost production from coffee pulp.

\section{Availability of data and materials}

Data is available and will be provided if need.

\section{Ethics approval and consent to participate}

The paper followed the ethics and consent to participate during the research work.

\section{Consent for publication}

I approved the manuscript for its publication.

\section{Competing interests}

The authors declare that he has no competing interests.

\section{References}

1. Abebe Sisay (2015). "Evaluation of Compost Stability and Maturity of Floriculture Solid Waste in a Windrow System". MSc. Thesis Submitted To School of Graduate Studies of Addis Ababa University, Addis Ababa, Ethiopia.

2. Alemayehu Haddis and Rani D. (2008). "Effect of Effluent Generated from Coffee Processing Plant on the Water Bodies and Human Health in its Vicinity". Journal of Hazardous Materials, 152 (4), 259262.

3. Andrea K., Headyn A., Jamroz E. and Bekier J. (2018). "The Dynamics of Some Physical and Physicochemical Properties during Composting of Municipal Solid Wastes and Biomass of Energetic Plants". Journal of waste management, 69 (3), 155-159.

4. Bayetta Bellachew (2001). Arabica Coffee Breeding for Yield and Resistance to Coffee Berry Disease (Colletotricum kahawah sp.). Doctoral Thesis, Imperial College Wye University, London. 
5. Bernal, M. , Alburquerque, J., and Moral, R., (2009). "Composting of Animal Manures and Chemical Criteria for Compost Maturity Assessment”. Journal of Bioresource Technology, 100 (22), 5444-5453.

6. Biotreat (2003). Interpretation of Results Report. National Food Biotechnological Centre, University College Cork, Ireland.

7. Brinton WF (2000). Compost Quality Standards and Guidelines: An International View. Woods Ends Research Laboratory, Interpretation of Waste and Compost Tests. Journal of the Wood and Research Laboratory, 1 (4), 1-6.

8. Dayanand S., Sudharsan V., Kunwar D., Yadav A. and Kalamdhad S. (2017). "Evolution of Chemical and Biological Characterization during Agitated Pile Composting of Flower Waste". International Journal of Recycle Organic Waste Agriculture, 6 (3), 89-98.

9. Dessalegn Dadi (2018). Valorization of Coffee Byproducts Via Biomass Conversion Technologies. Dissertation for Obtaining a Doctorate Degree at Jimma University, Jimma, Ethiopia.

10. Dessalegn Dadi, Hameed Sulaiman and Seyoum Leta (2012). "Evaluation of Composting and the Quality of Compost from the Source Separated Municipal Solid Waste". Journal of Environmental Management, 16 (1), 5-10.

11. EEPA (2004). Ethiopian Environmental Protection Authority (EFEPA). Guidelines on Composting, Addis Ababa, Ethiopia.

12. El-haddad M., Zayed M., and El-satar A. (2014). Evaluation of Compost, Vermicompost and their Teas Produced from Rice Straw as Affected by Addition of Different Supplements. Annals of Agricultural Sciences, 59 (2), 243-251.

13. Endale werako (2016). Composting of Coffee Husk and Pulp and Co-digest with other Organic MSc. Thesis Submitted To School of Graduate Studies of Addis Ababa University, Addis Ababa, Ethiopia.

14. Fan L., Soccol A., Pandey, A. and Soccol, C. (2003). "Cultivation of Pleurotus Mushrooms on Brazilian Coffee Husk and Effects of Caffeine and Tannic Acid". Journal of International Applied Microbiology, $15(1), 15-21$.

15. Fekadu Shemekit, Gomez B., Franke W., Praehauser, B., Insam H. (2014). “Coffee Husk Composting an Investigation of the Process Using Molecular and Non-Molecular Tools". Journal of Waste Management, 34 (3), 642-652.

16. Ferew Kebede (2012). "Management Strategies for Improving Manure Nutrient Use Efficiency and Productivity of Subsistent Farmers in Enset-based Farming Systems of Southern Ethiopia." Thesis Submitted To School of Graduate Studies of Addis Ababa University, Addis Ababa, Ethiopia.

17. Franca A., Oliveira L., (2009). Coffee Processing Solid Wastes: Current Uses and Future Perspectives. New York, Nova Publishers.

18. Gezahegn Degefe, Seyoum Mengistou and Said Mohammed (2016). "Physico-chemical Evaluation of Coffee Husk, Wastes of Enset (Enset Ventricosum ), Vegetable and Khat (Catha Edulis) Through Vermicomposting Employing an Epigeic Earthworm Dendrobaena Veneta" African Journal of Biotechnology, 15 (20), 884-890. 
19. Henok Kassa, and Tenaw Workayew (2014). "Evaluation of Some Additives on Coffee Residue (Coffee Husk and Pulp) Quality as Compost, Southern Ethiopia". International Invention Journal of Agricultural and Soil Science, 2 (2), 14-21.

20. Herity, L (2003). A Study of the Quality of Waste Derived Compost in Ireland. MSc. Thesis Submitted to School of Graduate Studies of Belfast Queens University, Ireland Belfast.

21. ICO, (2013). Coffee Trade statistics. International Coffee Organization.

22. Jayapriya, S., and Ravi, J. (2015). "Evaluation of In-vessel Co-composting of Yard Waste and Development of Kinetic Models for Co-composting". International Journal of Recycling of Organic Waste in Agriculture, 4 (3), 157-165.

23. Labouisse, J., Bayetta Bellachew, S. Kotecha and B. Bertrand (2008). "Current Status of Coffee (Coffea Arabica) Genetic Resources in Ethiopia: Implications for Conservation". Journal of Genetic Resource Crop Evolution, 55 (17), 1079-1093.

24. Liu, K. and Price G. (2011). "Evaluation of Three Composting Systems for the Management of Spent Coffee Grounds". Journal of Bioresource Technology 102(17), 7966-7974.

25. Mahabub Yusuf (2008). "Composting of Khat and Related Materials as Solid Waste Management option". MSc. Thesis Submitted To School of Graduate Studies of Addis Ababa University, Addis Ababa, Ethiopia.

26. Muno P. (2003). Analysis of Green Waste Compost from Dublin City Council and Interpretation of Results. GW 62, Dublin City, Bord Na Mona publisher.

27. Murthy P. and Naidu M. M. (2012). Sustainable Management of Coffee Industry By-products and Value Addition a Review. Resource Conservation Recycle, 66 (3), 45-58.

28. Pandey, A., Soccol, C., Nigan, P., Brand, D., Mohan, F. and Rovossos, S. (2000). "Biotechnological Potential of Coffee Pulp and Husk for Bio-process". Journal of Biochemical Engineer 6 (3), 153-162.

29. Preethu D., Prakash B., Srinivasamurthy C., and Vasanthi B. (2007). "Evaluate the Quality of Compost of Coffee Waste Blended with other Organic Wastes". International Journal of Solid Waste Management, 5 (3), 270-275.

30. Reyes-torres, M., Oviedo-ocana, E. R., Dominguez, I., Komilis, D., and Sanchez, A. (2018). "A Systematic Review on the Composting of Green Waste: Feedstock Quality and Optimization Strategies". Journal of Waste Management, 77 (6), 486-499.

31. Ryckeboer, J., Mergert, J., Coosemans, J., Deprins, K. and Swings, J. (2003b). "Microbiological Aspects of Bio-Waste during Composting in Monitored Compost Bin". Journal of Applied Microbiology, 94, 127-137.

32. Sahlemedhin Sestu and Taye Bekele (2000). Procedure for Soil and Plant analysis. Addis Ababa, Ethiopian Agricultural Research Organization.

33. Tadesse Getahun, Abebe Nigusie, Tafera Entele, Gerven, V. and Bruggen, D. (2012b). "Effect of Turning Frequencies on Composting Biodegradable Municipal Solid Waste Quality". Journal of Resources, Conservation and Recycling, 65 (2), 79-84. 
34. Tadesse Woldemariam, and Feyera Senbeta (2008). Sustainable Management and Promotion of Forest Coffee in Bale. Ethiopia, Bale Eco-Region Sustainable Management Program SOS Sahel/FARM-Africa.

35. Tandon S., (2005). Fertilizers, Organic Manures and Bio-fertilizers. New Delhi, India. Fertilizer Development and Consultation Organization.

36. Taye Kufa (2013). Status of Arabica Coffee Germplasm in Ethiopia. Ethiopia, EIAR/Jimma Research Center.

37. Tiquia, S., Wan, J., and Tam, N. (2002). "Microbial Population Dynamics and Enzyme Activities during Composting”. Journal of Environmental Pollution, 110 (3), 535-541.

38. USCC, (2003). Soil Test Analysis Test Parameters. Test Methods for the Examination of Composting and Compost.

39. Vega, F. , (2008). The Rise of Coffee. Journal of American Scientist, 96 (2), 138-145.

40. Wang P., Changa C., Watson M., Dick W., Chen Y., and Hoitink H. (2004). "Maturity Indices for Composted Dairy and Pig Manures". Journal of Soil Biology and Biochemistry, 36 (7), 767- 776.

41. Zhang J., Chen G., Sun H., Zhou S., and Zou G., (2016). "Straw Biochar Hastens Organic Matter Degradation and Produces Nutrient Rich Compost". Journal of Bioresource Technology, 200 (12), 876-883.

\section{Figures}




\section{Map of the Study Area}

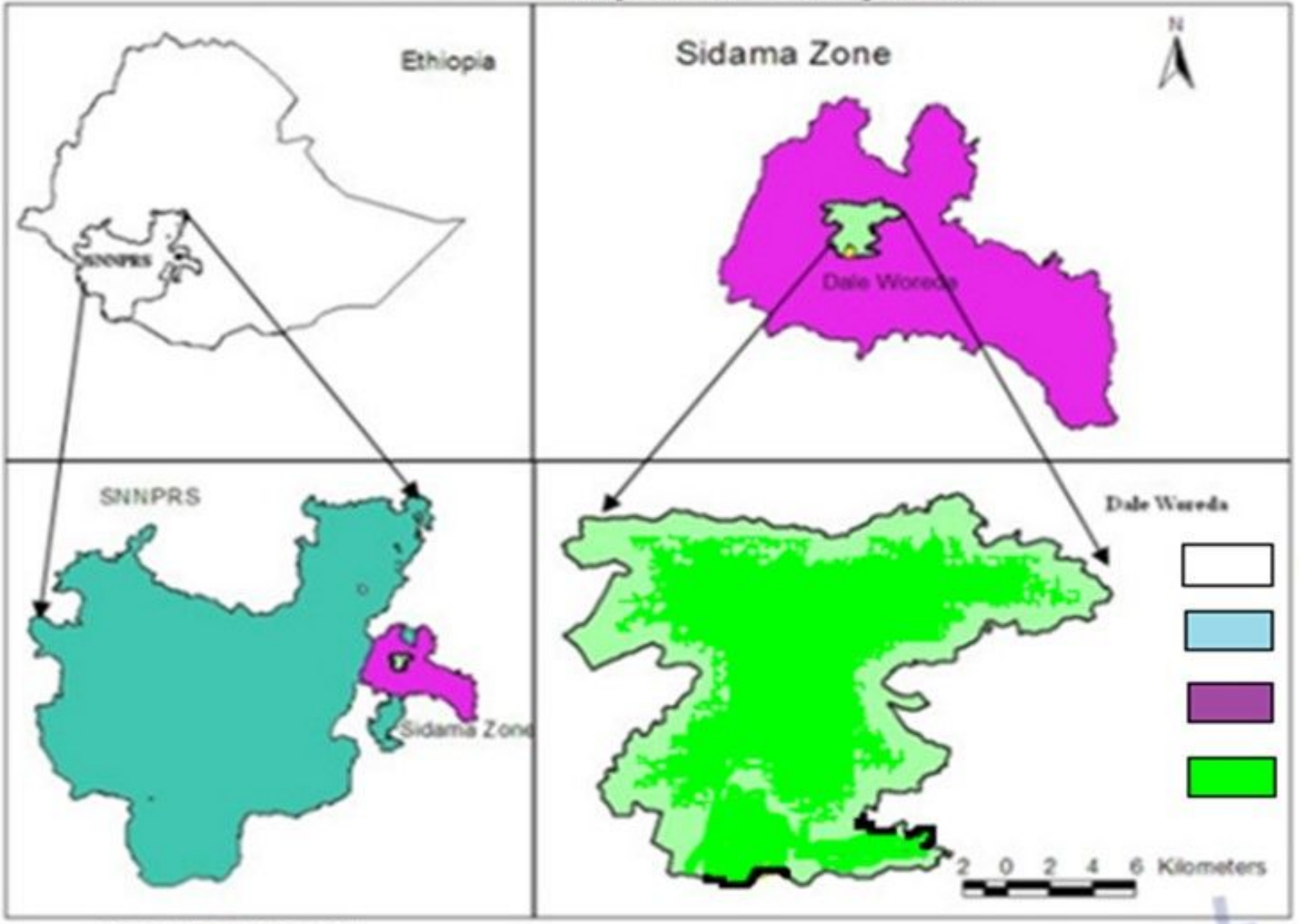

Ethiopia

SNNPR

Sidama Zone

Dale district

Figure 1

Map of Study Area.

Block 1
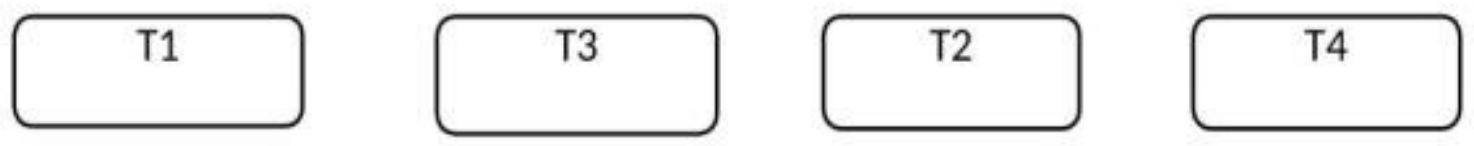

Block 2
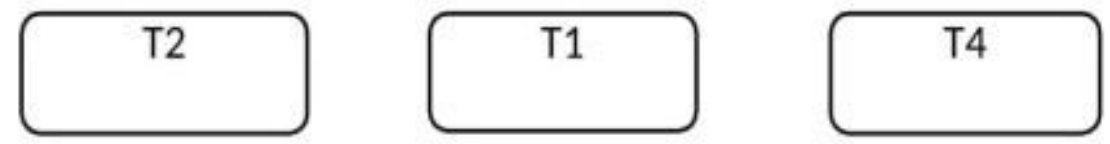

T3

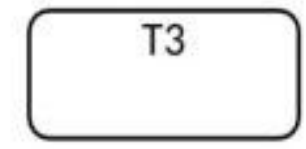

Block 3
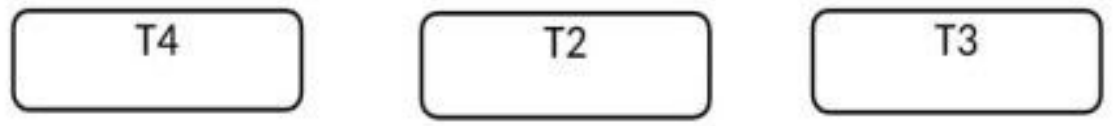

T1

Figure 2

Randomized complete block design arrangement. T1: Treatment 1 (CP) T2: Treatment 2 (CP and CD) T3: Treatment 3 (CP and EL) T4: Treatment 4 (CP, CD and EL) 


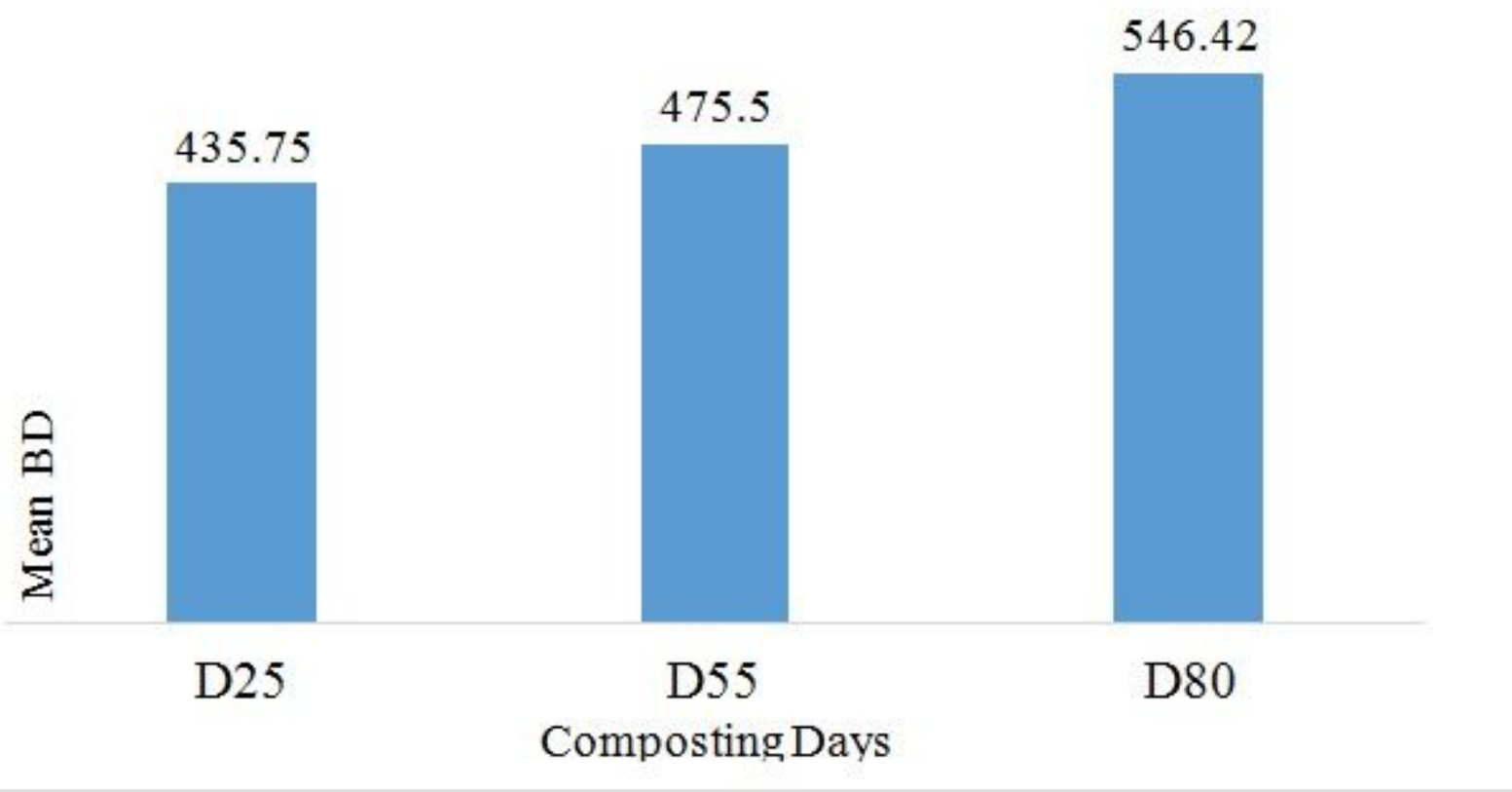

Figure 3

Mean Bulk density at different time of composting.

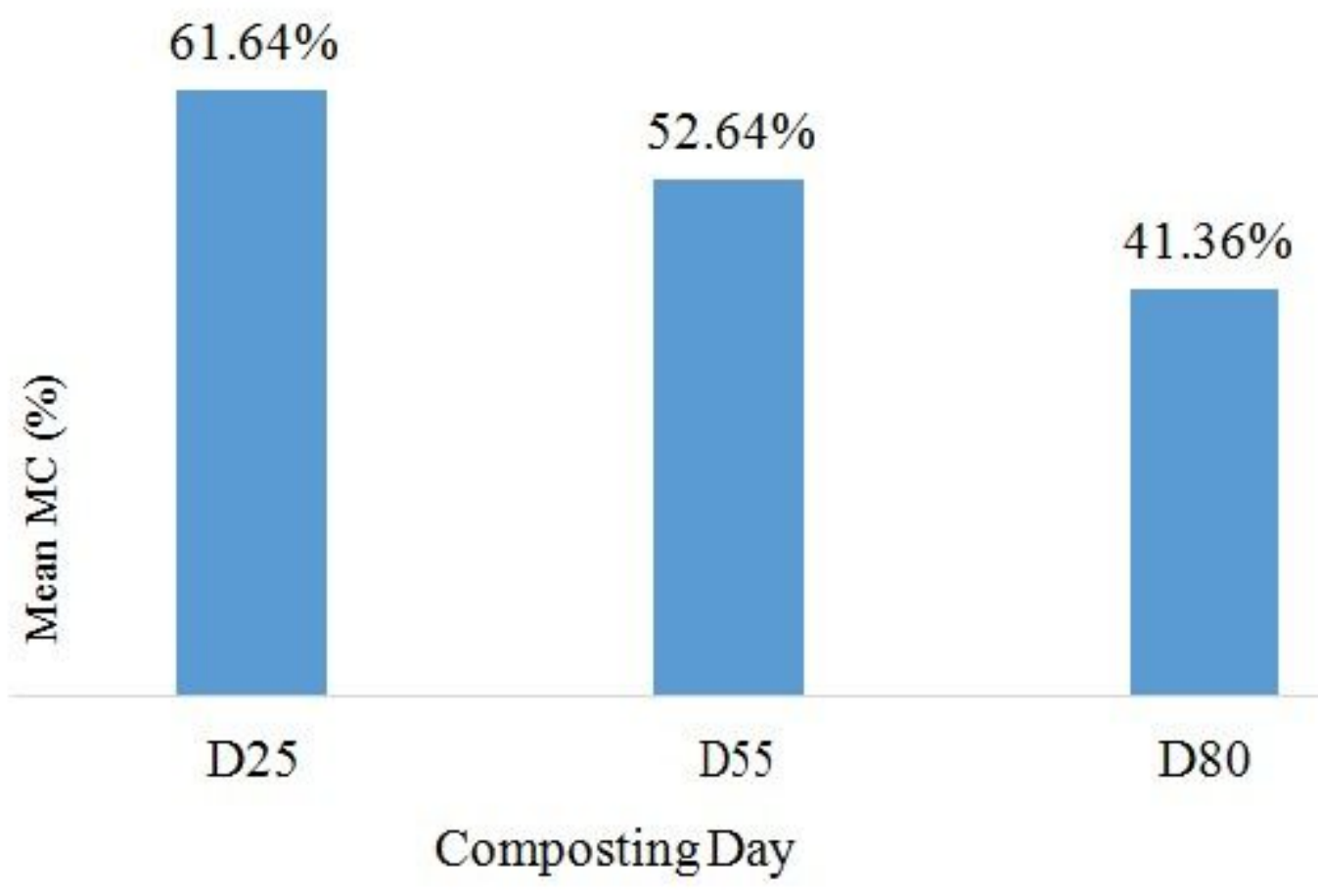

Figure 4

Mean moisture content at different time of composting. 


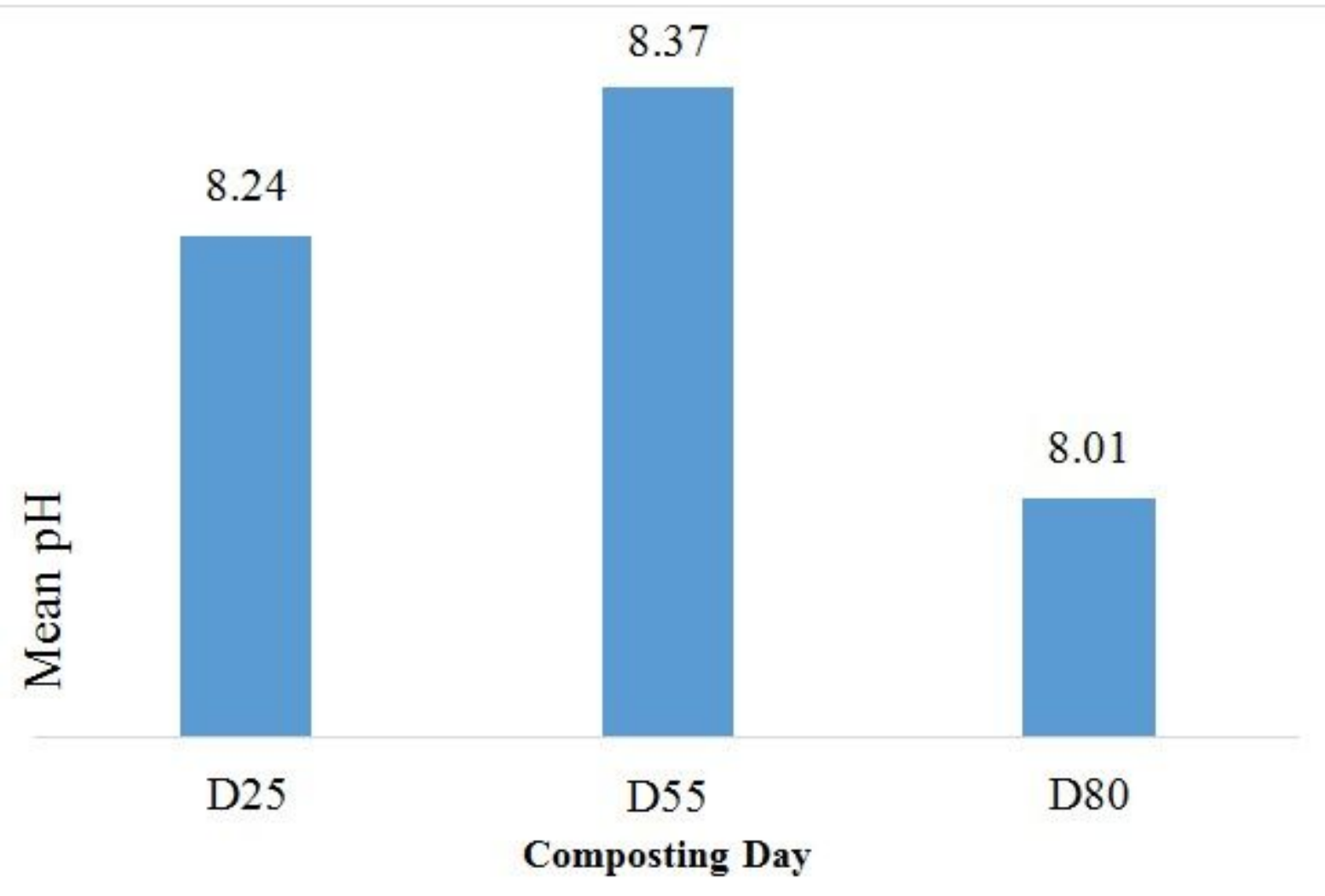

Figure 5

Mean $\mathrm{pH}$ at different time of composting.

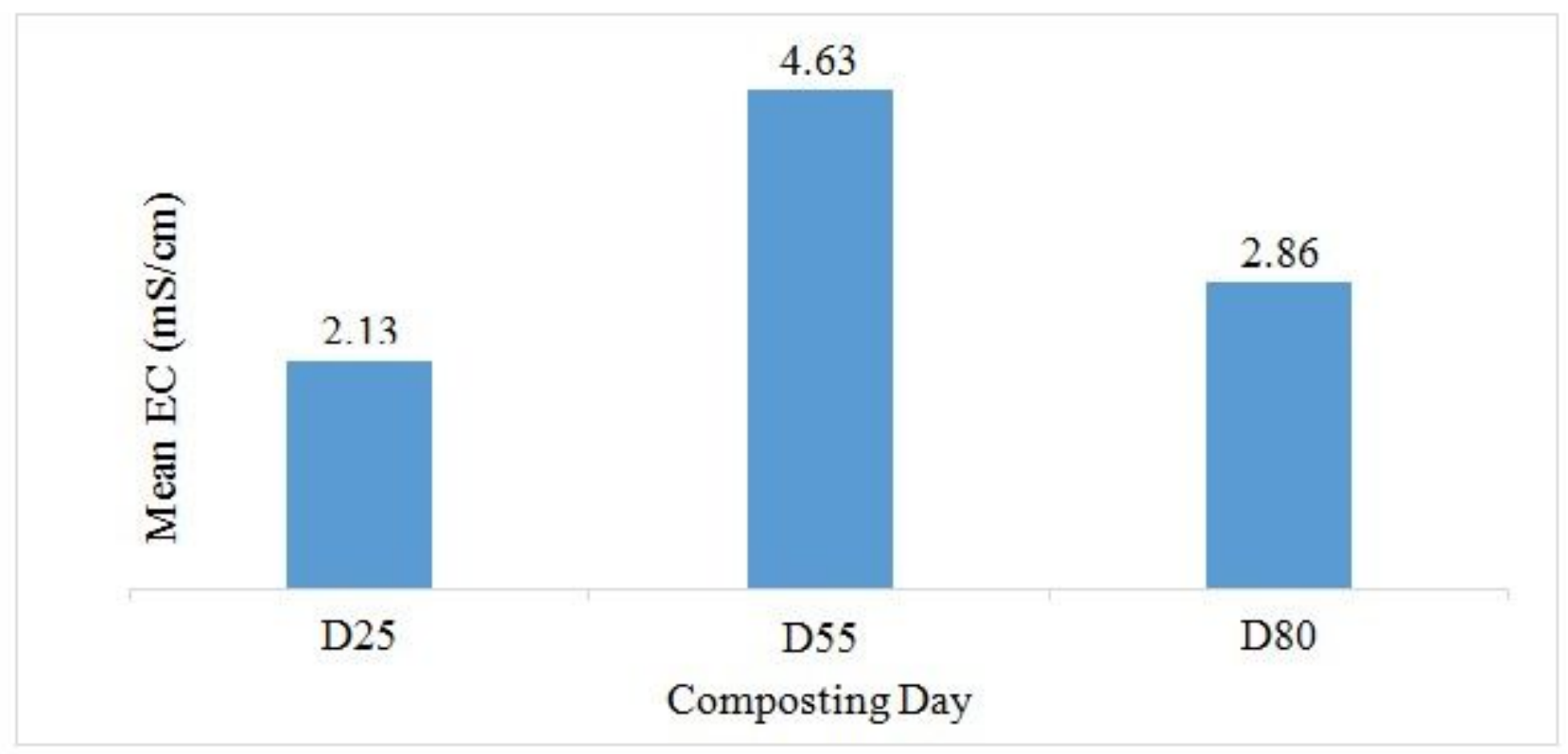

Figure 6

Mean electrical conductivity at different time of composting. 


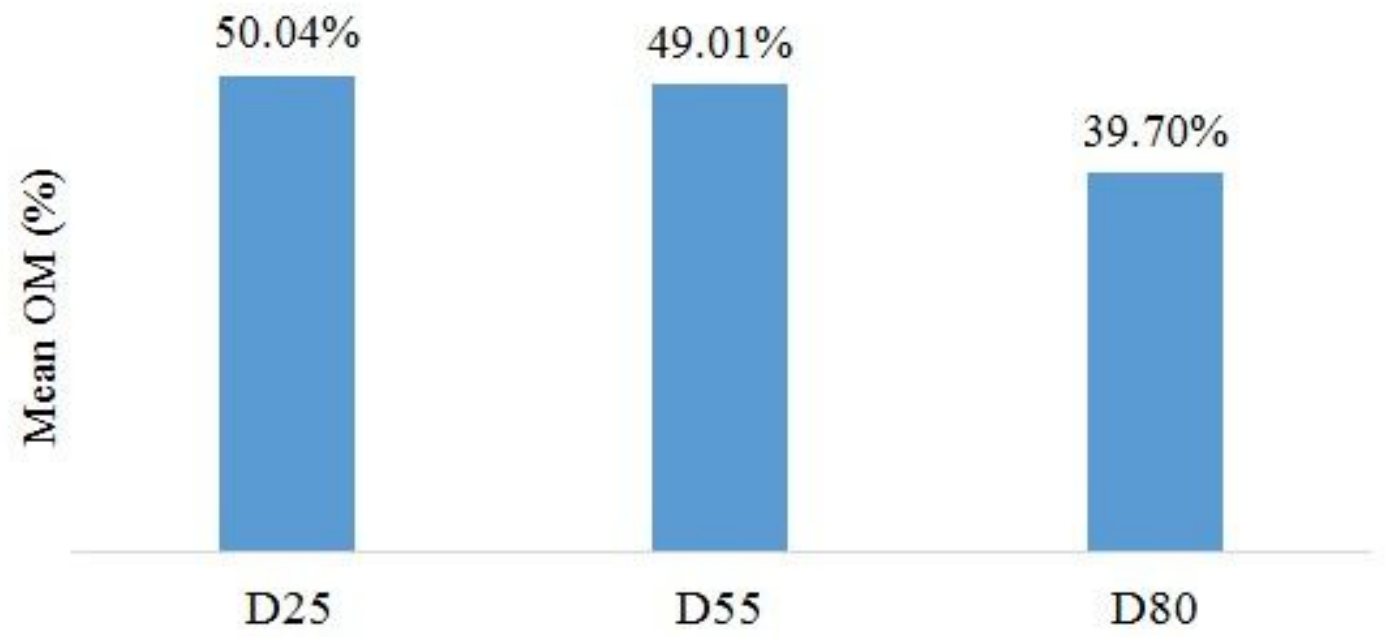

Composting Dav

Figure 7

Mean organic matter at different time of composting.

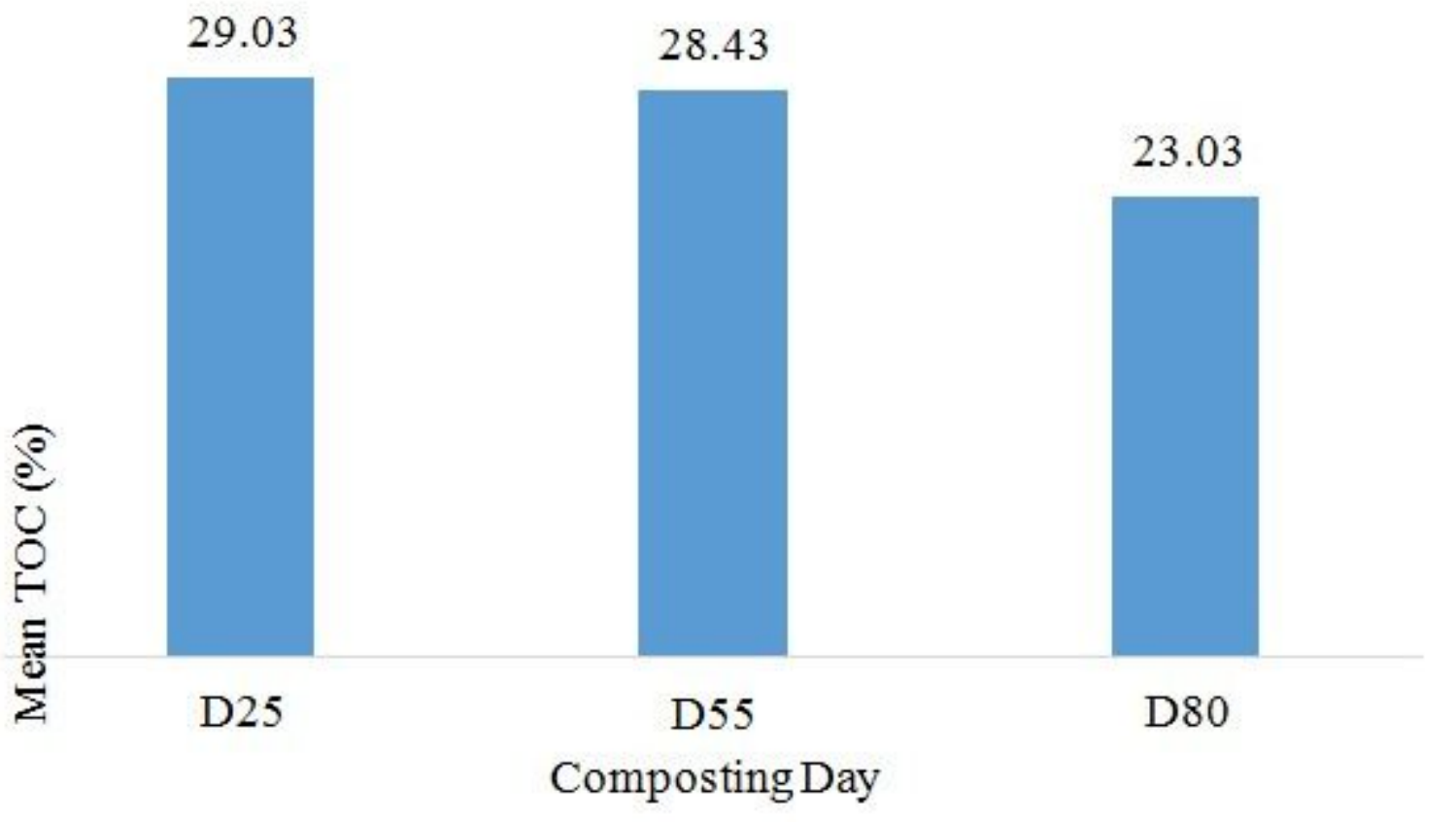

Figure 8

Mean total organic carbon at different time of composting. 


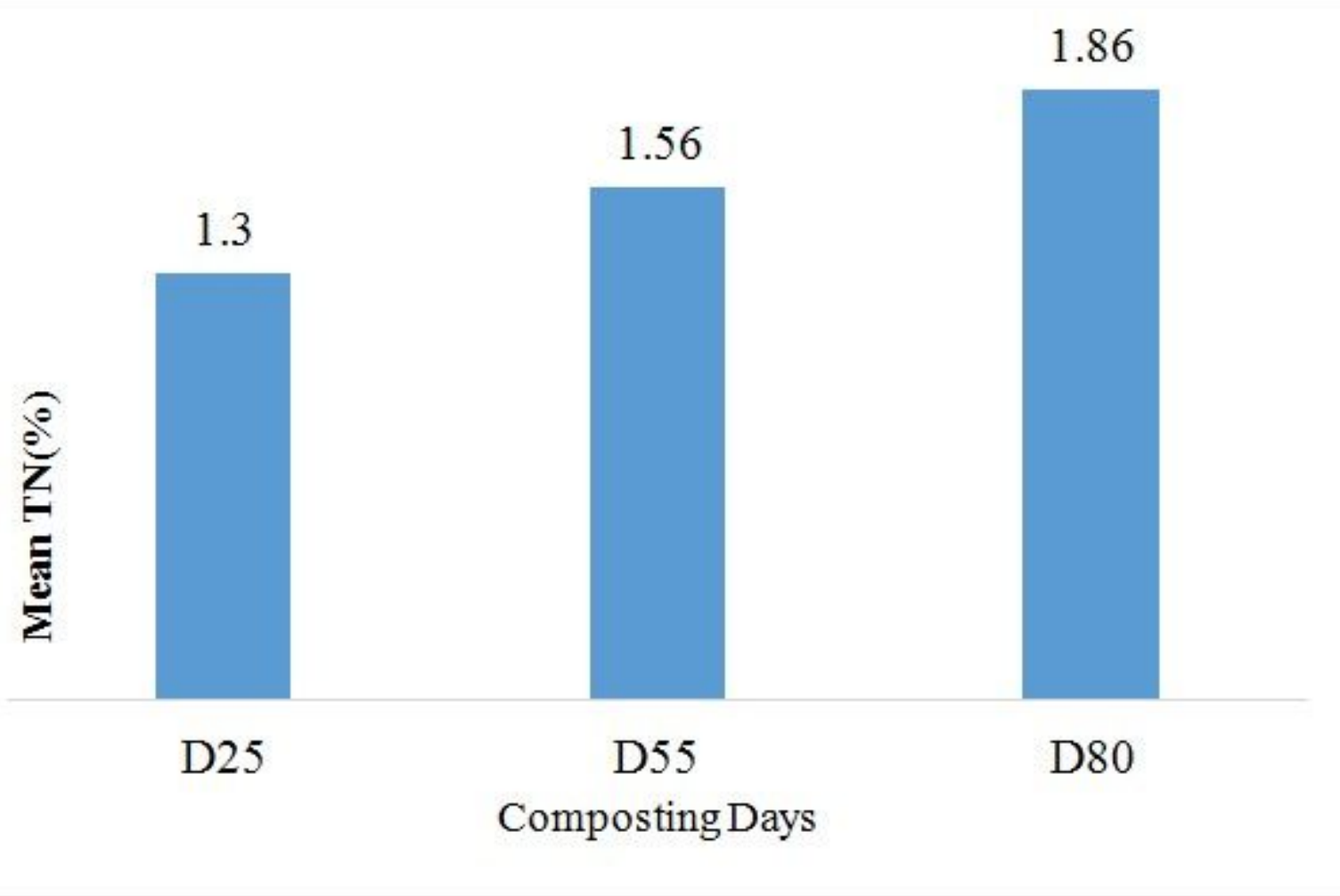

Figure 9

Mean total nitrogen content at different time of composting.

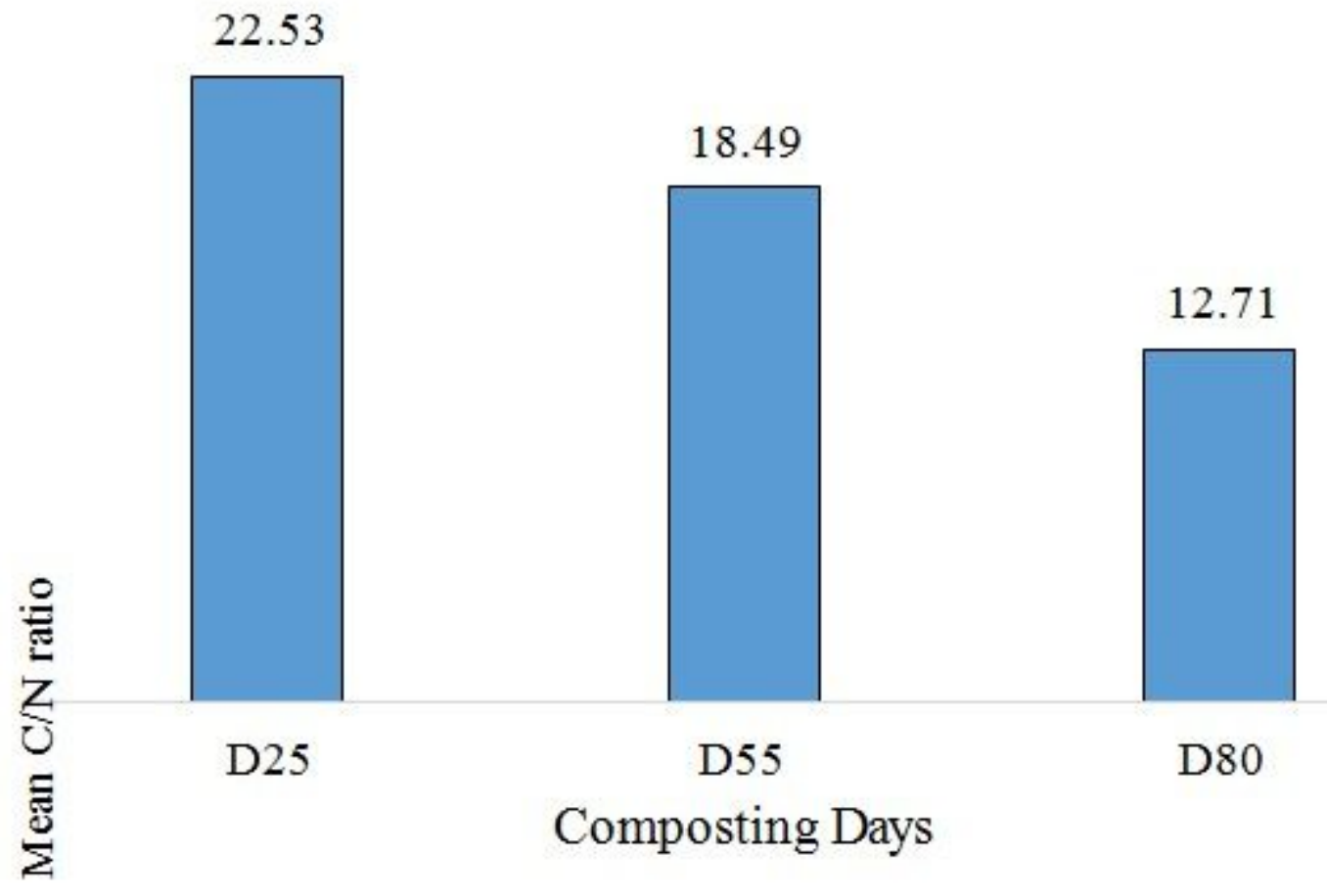

Figure 10 
Mean carbon to nitrogen ratio at different time of composting.

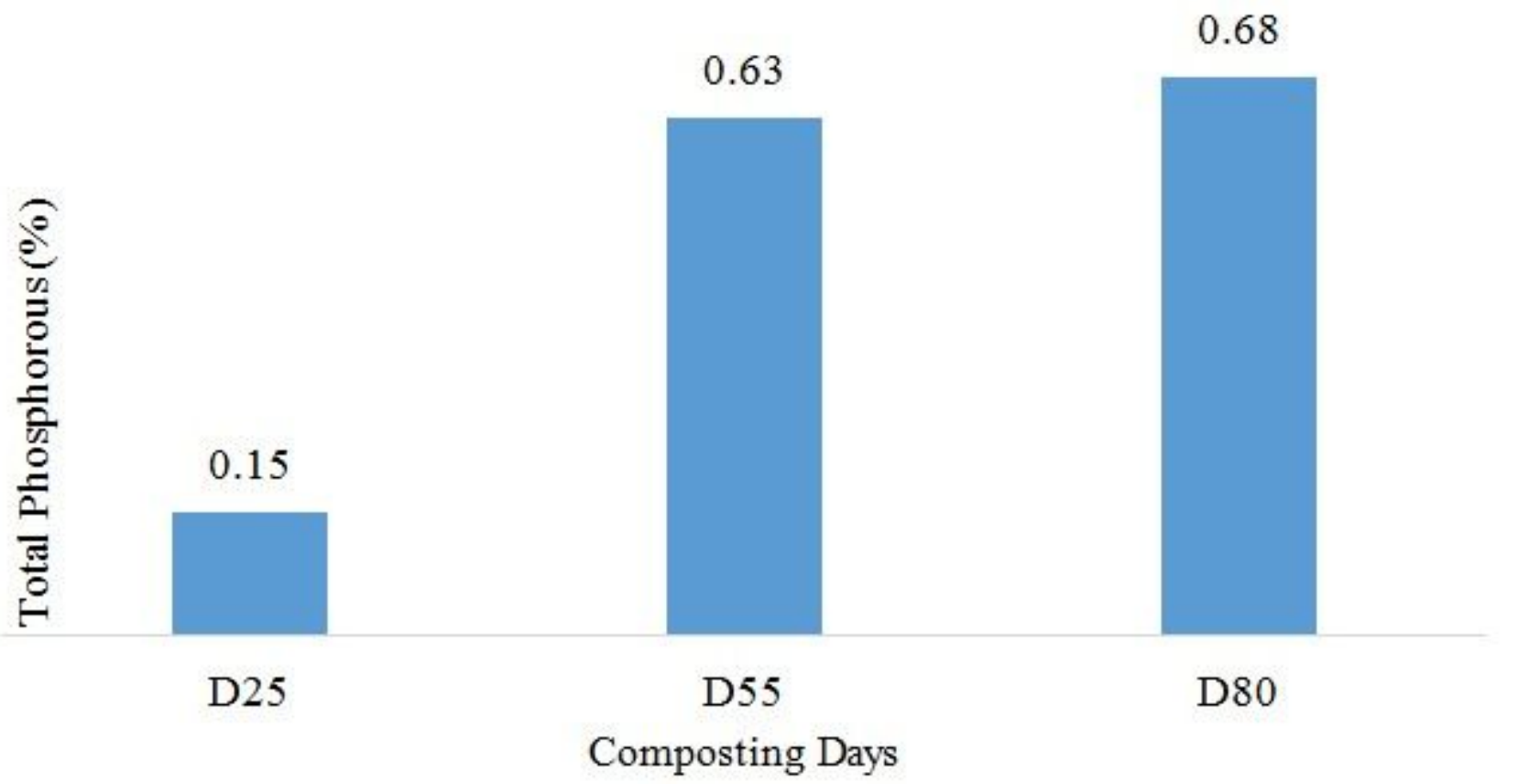

Figure 11

Mean total phosphorous at different time of composting.

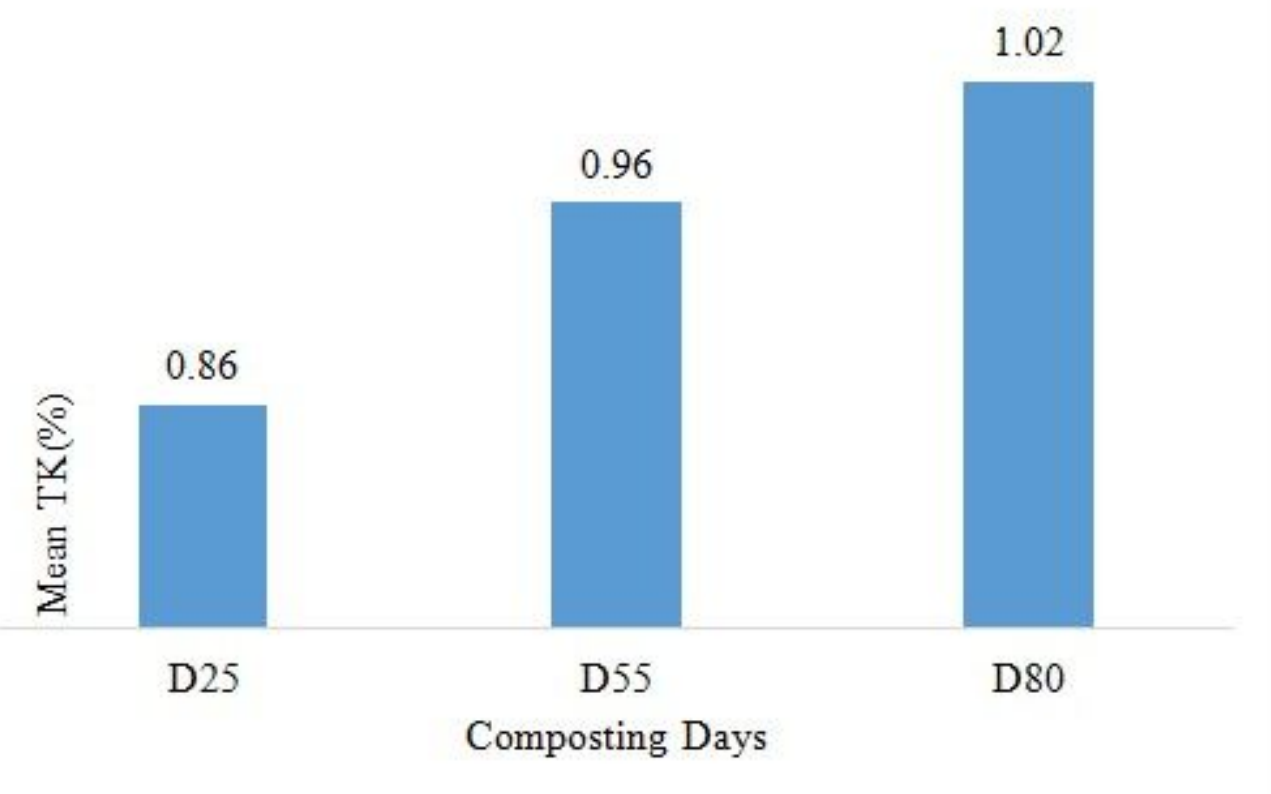

Figure 12

Mean total potassium at different time of composting. 